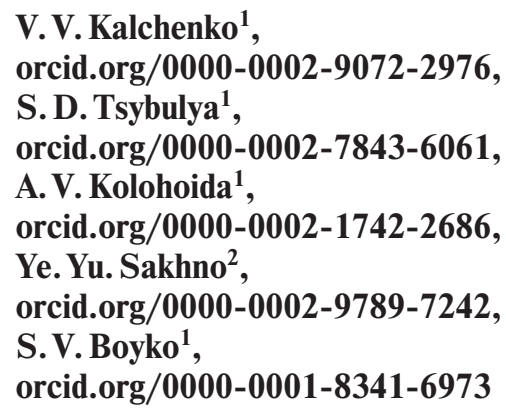

1 - Chernihiv Polytechnic National University, Chernihiv, Ukraine, e-mail: svboyko.cstu@gmail. com

2 - Chernihiv State Institute of Economics and Management, Chernihiv, Ukraine

\title{
DETERMINATION OF THE CUTTING FORCE COMPONENTS WHILE MILLING CYLINDRICAL SURFACES WITH AN ORIENTED TOOL
}

Purpose. Construction of a general modular mathematical spatial model of the removal allowance process and shaping when milling round surfaces of rotation, such as camshaft necks, cylindrical surfaces of gearbox shafts and others. Determination of the components of the cutting forces when machining with crossed axes of the milling cutter and part in order to use the results when assigning machining modes.

Methodology. Theoretical development of a modular mathematical model of the removal allowance process and shaping during milling of cylindrical surfaces was carried out using a matrix apparatus for converting coordinate systems. Unified modules were developed: instrumental, orientation and shaping, which allowed us to describe the processing of the part more clearly. All calculations were performed in the mathematical package Mathcad. Using the functions available in the package, a graphical representation of the mathematical model of the tool and machined surfaces was obtained. Using the logical blocks developed in the program, the characteristics of the treated surface were investigated, such as roughness in the axial and radial planes. The influence of the tool orientation angle and the number of cutter teeth on the roughness of the machined surface was investigated. The known formulas for calculating the cutting forces during milling are specified.

Findings. A general modular mathematical spatial model is constructed of the removal process of an allowance and formation at milling by the oriented tool of round surfaces of rotation, such as necks of camshafts, cylindrical surfaces of shafts of transmissions and others. The roughness parameters of the treated surface are determined. The outflow of the tool characteristics and the angle of its orientation on the geometric roughness in the axial and radial sections is investigated. The area of the layer cut off by one tooth of a mill is defined. The calculation formulas are specified for finding the components of cutting forces during milling.

Originality. A modular spatial model of the process of milling cylindrical surfaces with an oriented tool is proposed, on the basis of which the components of cutting forces are calculated, which can be used in designing new tools and improving machining conditions by the existing ones.

Practical value. Based on the use of modern computer facilities and software, the developed calculation program allows controlling the process of forming cylindrical surfaces during their milling with an oriented tool. It also allows predicting the initial machining accuracy by determining the parameters of geometric roughness in axial and radial sections. This makes it possible to choose the optimal tool orientation angle, milling cutter parameters and cutting modes to achieve high productivity and processing quality.

Keywords: cutting forces, milling, camshaft, grinding, modeling, roughness

Introduction. A significant number of operations for the manufacture of various parts refer to the methods of cutting. In this case, the final quality and accuracy of the parts are provided mainly by grinding operations. However, it is known that grinding operations with abrasive and diamond wheels require more energy consumption compared to blade processing methods. At present, considerable attention is paid to the creation of new technologies and schemes of blade processing, which will ensure a sufficiently high quality of parts and eliminate the need for grinding operations.

In order to improve the quality of the treated surface after milling, prefabricated milling cutters are used with replaceable multifaceted plates. Thus, for more detailed studying of process of milling the round surfaces of basic necks of a camshaft and cylindrical surfaces of transmission shafts, it is necessary to conduct mathematical modeling of the cutting scheme. In the course of spatial modeling, it is necessary to determine the mathematical model of the tool surface, the general modular spatial model of the process of removal of allowance and shaping. On the basis of the developed models, the parameters of the initial roughness of the treated surface and the components of the cutting force are to be investigated. This will make it possible to investigate the milling process in more detail and

(C) Kalchenko V.V., Tsybulya S. D., Kolohoida A. V., Sakhno Ye. Yu., Boyko S. V., 2021 use the obtained dependences to rationally choose the cutting mode and geometric characteristics of the tool.

Literature review. Modeling of cutting processes is becoming more and more widespread [1]. They use a variety of applications and applications. Systems of virtual modeling of all stages of creation of details and each separate operation are common [2], in particular CAM of system of modeling of processing on CNC machines [3]. With the help of special software one can predict the processing time and some of its parameters $[4,5]$.

Studies on the cutting process during milling are usually performed using a flat machining scheme [6, 7]. However, as a result of such simplification, insufficiently accurate values of the area of the cut layer and other parameters of the cutting process are obtained. In addition, in the field of blade processing there is no method of comprehensive study on the process of chip removal and shaping. At the same time, each of the issues is described separately, as a result of which the completeness of the research is lost and some distortion of the obtained results is observed.

A comprehensive study on the process of chip removal and shaping is considered by the authors [8,9]. In [8] the process of grinding with an oriented abrasive wheel is investigated. For the selected processing scheme the scheme of editing of a circle is offered and mathematical models on the basis of unified modules are developed. In [9], a method of milling the sup- 
port necks and cams of the camshaft for one institution with a special disk milling cutter is proposed. The productivity of milling, as well as the dependence of the distribution of specific productivity along the cutting blade is determined.

Much attention is paid to the methods for calculating the cutting forces during machining [10], as it improves the understanding of the processes of removal of allowance and shaping, and allows predicting the initial accuracy of the part and the quality of the surface layer.

Unsolved aspects of the problem. For a more rational choice of cutting modes for milling according to existing schemes and production of new processing methods and tool designs, it is necessary to carry out mathematical spatial modeling of the tool surface, the process of removing allowance and shaping when milling round surfaces such as camshaft support cylinders and cylinders gears. On the basis of the developed model it is necessary to carry out research on influence of parameters of the tool on quality of a detail by definition of components of cutting forces and geometrical roughness of the processed surface.

Purpose. Construction of a general modular mathematical spatial model of the process of removal of allowance and shaping when milling round surfaces of rotation, such as camshaft necks, cylindrical surfaces of gearbox shafts and others. Further, on its basis, the determination of the components of the cutting forces when machining with crossed axes of the milling cutter and part in order to use the results when assigning machining modes.

Results. Currently, grinding schemes with crossed tool axes and parts are known (Fig. 1).

According to this scheme, the grinding wheel 1 and the part 2 rotate around their own axes with a constant frequency; the part 2 additionally performs the feed movement $S_{p}$, along the axis $Z_{p}$. In order to distribute the allowance along the periphery of the grinding wheel, the tool is oriented relative to the part by rotating it at an angle $\alpha$ relative to the $Y_{g r}$ axis.

Based on the developed model of allowance removal and shaping during grinding with an oriented tool, the position of the instantaneous contact spot and its area, as well as the thickness of the cut layer are determined. And by determining the number of cutting and deforming edges involved in the machining process calculate the unit and total cutting force.

The milling scheme of the camshaft support necks (Fig. 2) does not differ significantly from the grinding process. The disk prefabricated milling cutter 1 rotates around its own axis. The part 2, in addition to rotation, performs a longitudinal feed movement. To improve the processing conditions, the milling cutter is rotated by an angle $\alpha \mathrm{m}$ relative to the $Y_{m}$ axis.

Due to the introduction of the angle of orientation of the tool, the beginning of the removal of the allowance falls on the end surface; in addition, the depth of cut decreases when approaching the radial edge and periphery. The axis of rotation

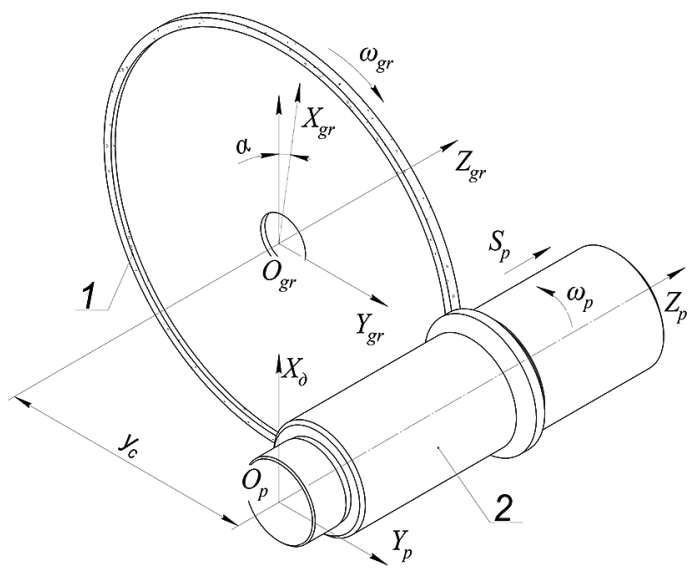

Fig. 1. Grinding scheme with crossed wheel axes and parts

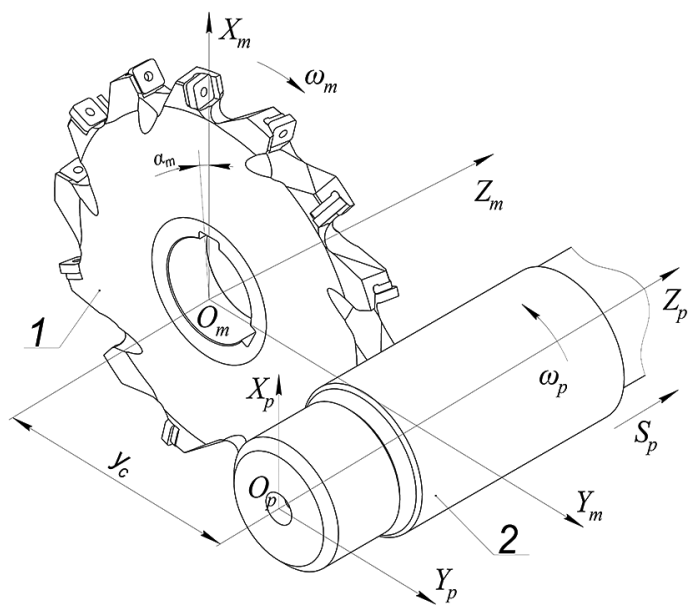

Fig. 2. Scheme of milling a cylindrical surface with an oriented tool

of the milling cutter is separated from its end by a certain amount of $C$. This distance determines the presence of the calibration particle and determines its length. Thus, the allowance for removal by the peripheral cutting edge is also evenly distributed along the length of the blade. This unloads the cutting edge and reduces the wear intensity of the replaceable multifaceted blade, and accordingly increases its service life.

Let us carry out mathematical modular spatial modeling of the scheme of milling of cylindrical surfaces (Fig. 2). To do this, we define a mathematical model of the tool surface. Processing is performed by a prefabricated milling cutter with insert replaceable multifaceted plates; the number of plates and the nature of their installation are determined by the design of the milling cutter. According to the proposed milling scheme, the removal of the allowance is carried out by the end surface of the plate, its periphery and the transition radial edge (Fig. 3). Since the tool rotates around its own axis, the contour formed by two rectilinear and one radial section forms a continuous cylindrical tool surface. To write mathematical models, we use coordinate transformation matrices and special unified modules. Therefore, the surface of the milling cutter can be determined by a cylindrical module (1) with two independent parameters

$$
\bar{r}_{m}\left(\theta_{m}, i\right)=C_{Z_{m}(i) \cdot \theta_{m} \cdot R_{m}\left(z_{i}\right)}^{T} \cdot \bar{e} 4,
$$

where $\bar{r}_{m}\left(\theta_{m}, i\right)$ is the radius vector of the milling cutter surface; $C_{Z_{m}(i) \cdot \theta_{m} \cdot R_{m}\left(z_{i}\right)}^{T}$ is the cylindrical module of the work surface milling; $\bar{e} 4=\left(\begin{array}{llll}0 & 0 & 0 & 1\end{array}\right)^{T}$ is the radius vector of the origin of the coordinate system; $Z_{m}(i)$ is a coordinate along the axis $O_{m} Z_{m}$ (Fig. 3) of the tool surface at some $i^{\text {th }}$ point, mm; $\theta_{m}$

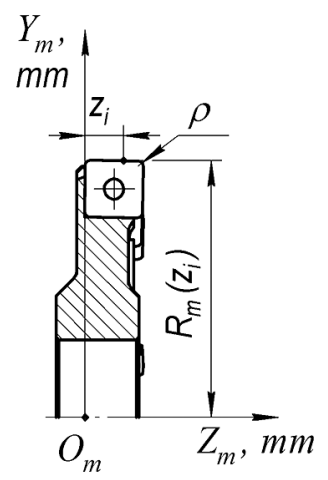

Fig. 3. Scheme for determining the mathematical model of the working surface of the milling cutter 
is the current angle of rotation of the milling cutter point around the axis $O_{m} Z_{m}$, radian; $R_{m}\left(z_{i}\right)$ is the radius of the tool surface at some $i^{\text {th }}$ point, mm.

The dependence of the current coordinate $Z_{m}(i)$ and radius of the work surface $R_{m}\left(z_{i}\right)$ at the $i^{\text {th }}$ point of the profile can be written using the Heaviside function

$$
\begin{gathered}
Z_{m}(i)=i \cdot\left(1-\Phi\left(i-i_{\rho}\right)\right)+ \\
+\left(i_{\rho}+\rho\right) \cdot \Phi\left(i-\left[i_{\rho}+\rho \cdot \frac{\pi}{2}\right]\right)+\left(i_{\rho}+\rho \cdot \sin \frac{i-i_{\rho}}{\rho}\right) \times \\
\times\left[\Phi\left(i-i_{\rho}\right)-\Phi\left(i-\left[i_{\rho}+\rho \cdot \frac{\pi}{2}\right]\right)\right] ; \\
R_{m}\left(z_{i}\right)=R \cdot\left(1-\Phi\left(i-i_{\rho}\right)\right)+\left[R-\rho-i+\left(i_{\rho}+\rho \cdot \frac{\pi}{2}\right)\right] \times \\
\times \Phi\left(i-\left[i_{\rho}+\rho \cdot \frac{\pi}{2}\right]\right)+\left[R+\rho \cdot\left(\cos \frac{i-i_{\rho}}{i}-1\right)\right] \times \\
\times\left[\Phi\left(i-i_{\rho}\right)-\Phi\left(i-\left[i_{\rho}+\rho \cdot \frac{\pi}{2}\right]\right)\right],
\end{gathered}
$$

where $i$ is the current coordinate on the cutting surface of the milling cutter along the axis $O_{m} Z_{m}, \mathrm{~mm} ; i_{\mathrm{\rho}}$ is the coordinate of the starting point of the radial section on the variable polyhedral plate along the axis $O_{m} Z_{m}, \mathrm{~mm}$; $\rho$ is the radius of rounding of a hard-alloy plate, $\mathrm{mm}$.

In equations $(2,3)$, the first term characterizes the peripheral area of the tool surface, the second - the end, and the third - the transitional radial edge. The Heaviside function determines the position of each section on the coordinate plane.

The mathematical model of the tool surface of the milling cutter using coordinate transformation matrices has the form

$$
\begin{gathered}
\bar{r}_{m}\left(\theta_{m}, i\right)=C_{Z_{m}(i) \cdot \theta_{m} \cdot R_{m}\left(z_{i}\right)}^{I} \cdot \bar{e} 4= \\
=M^{3}\left(Z_{m}(i)\right) \cdot M^{6}\left(\theta_{m}\right) \cdot M^{2}\left(R_{m}\left(z_{i}\right)\right) \cdot \bar{e} 4
\end{gathered}
$$

where $M^{3}, M^{2}$ are single-coordinate transformation matrices of the coordinate systems describing, respectively, the movement along the axes $O_{m} Z_{m}$ and $O_{m} Y_{m} ; M^{6}$ is the matrix that describes the rotation around the axis $O_{m} Z_{m}$.

To record a mathematical model of the treated surface, it is necessary to transfer the tool to the coordinate system of the part and set the shaping movements.

The relative position of the workpiece and the milling cutter is determined by the orientation module and the transition matrix. The transition nut sets the center distance

$$
M^{m}=M^{2}\left(y_{c}\right),
$$

where $y_{c}$ is an interaxial distance, $\mathrm{mm}$.

And the orientation module determines the specific position of the tool relative to the workpiece. Since the processing is proposed to be carried out with a cutter rotated at an angle $\alpha_{m}$ around the axis $O_{m} Y_{m}$, and the axis of the rotor enters at a certain distance from the end of the cutter, the orientation module has the form

$$
C_{\alpha_{m} \cdot C}^{O}=M^{5}\left(\alpha_{m}\right) \cdot M^{3}(C),
$$

where $C_{\alpha_{m} \cdot C}^{O}$ is an orientation module; $\alpha_{m}$ is an angle of rotation of the milling cutter, rad; $C$ is the distance from the end of the cutter to the axis of its rotation, which determines the length of the calibration section, $\mathrm{mm}$.

In the relative motion of the milling cutter and the cylindrical surface of the camshaft, the milling cutter performs a helical movement, while the surface of the part is considered immovable. Then the shaping module can be written

$$
C_{Z_{p} \cdot \theta_{p}}^{F}=M^{3}\left(Z_{p}\right) \cdot M^{6}\left(\theta_{p}\right),
$$

where $C_{Z_{p} \cdot \theta_{p}}^{F}$ is the shaping module; $z_{p}$ is the magnitude of the movement of the axis of the milling cutter along the surface of the part, $\mathrm{mm} ; \theta_{p}$ is the angle of rotation of the part, which determines the frequency of its rotation, rad.

The distance at which the tool moves relative to the initial position of parts when turning the shaft at an angle $\theta_{p}$ is calculated from the expression

$$
Z_{p}=\theta_{p} \cdot t
$$

where $t=\frac{S_{p}}{2 \cdot \pi}$ is a parameter of screw relative movement of a mill, $\mathrm{mm} / \mathrm{rad} ; S_{p}$ is axial supply of a detail, $\mathrm{mm} / \mathrm{rev}$.

Therefore, the equation of the treated surface can be written as

$$
\bar{r}_{m}\left(\theta_{p}, \theta_{m}, i\right)=C_{Z_{p} \cdot \theta_{p}}^{F} \cdot C_{\alpha_{m} \cdot C}^{O} \cdot M^{m} \cdot \bar{r}_{m}\left(\theta_{m}, i\right) .
$$

Substituting expressions (4-8) in equation (9), we obtain a mathematical model of the treated surface

$$
\begin{gathered}
\bar{r}_{p}\left(\theta_{p}, \theta_{m}, i\right)=M^{3}\left(\theta_{p} \cdot t\right) \frac{S_{p}}{2 \cdot \pi} \cdot M^{6}\left(\theta_{p}\right) \times \\
\times M^{5}\left(\alpha_{m}\right) \cdot M^{3}(C) \cdot M^{2}\left(y_{c}\right) \times \\
\times M^{3}\left(Z_{m}(i)\right) \cdot M^{6}\left(\theta_{m}\right) \cdot M^{2}\left(R_{m}\left(z_{i}\right)\right) \cdot \bar{e} 4 .
\end{gathered}
$$

Since equation (10) has three parameters and describes a family of surfaces, it is necessary to additionally introduce the condition of formation. It is known that the formation of the final profile of the part occurs at the point where the equality is performed

$$
\bar{V} \cdot \bar{n}=0,
$$

where $\bar{n}$ is a normal to the treated surface, it can be defined as a vector product of tangents; $\bar{V}$ is the vector of the relative speed of the tool relative to the part.

Tangents are determined by differentiating the radius-vector of the surface of the part by the angle of rotation of the tool surface $\theta_{m}$ and the current coordinate and on the cutting surface of the cutter. We will obtain

$$
\bar{n}=\frac{\partial \bar{r}_{p}\left(\theta_{p}, \theta_{m}, i\right)}{\partial \theta_{m}} \times \frac{\partial \bar{r}_{p}\left(\theta_{p}, \theta_{m}, i\right)}{\partial i} .
$$

The relative velocity vector $\bar{V}$ is a differentiation of the radius vector $\bar{r}_{p}\left(\theta_{p}, \theta_{m}, i\right)$ at the angle of rotation of the detail $\theta_{p}$

$$
\bar{V}=\frac{\partial \bar{r}_{p}\left(\theta_{p}, \theta_{m}, i\right)}{\partial \theta_{p}} .
$$

Therefore, the condition of formation (11) taking into account $(12,13)$ can be represented as

$$
\left(\frac{\partial \bar{r}_{p}\left(\theta_{p}, \theta_{m}, i\right)}{\partial \theta_{m}} \times \frac{\partial \bar{r}_{p}\left(\theta_{p}, \theta_{m}, i\right)}{\partial i}\right) \cdot \frac{\partial \bar{r}_{p}\left(\theta_{p}, \theta_{m}, i\right)}{\partial \theta_{p}}=0 .
$$

To find the solution of this equality, and hence the points of contact of the detail and the tool, we use the logic block

$$
L=\mid \begin{aligned}
& d \rightarrow 0 \\
& \text { for } q \in 0 \ldots N \\
& d \leftarrow d_{\min }+\frac{d_{\max }-d_{\min }}{N} \cdot q \\
& R \leftarrow \operatorname{root}\left[\left(\frac{\partial \bar{r}_{p}}{\partial \theta_{m}} \times \frac{\partial \bar{p}_{p}}{\partial i}\right) \cdot \frac{\partial \bar{r}_{p}}{\partial \theta_{p}}, d\right] \\
& M^{\langle q+1\rangle} \leftarrow\left(\begin{array}{l}
d \\
R
\end{array}\right) \\
& M^{T}
\end{aligned}
$$


where $N$ is the total number of segments into which the contact line is divided; $d_{\min }, d_{\max }$ are initial and final coordinates of the contact line at the periphery of the cutting edge of the milling cutter; $q$ is the additional parameter that determines the sequence number of the point of the contact line; $M$ is the matrix in which the calculation results are stored.

As a result of the calculation of the block (14), we obtain the points belonging to the contact line of the cutter and the cylindrical surface of the camshaft. Interpolation functions are used to obtain a continuous line

$$
L c(i)=\operatorname{interp}\left(\operatorname{cspline}\left(L^{\langle 1\rangle}, L^{\langle 2\rangle}\right), L^{\langle 1\rangle}, L^{\langle 2\rangle}, i\right),
$$

where $L c(i)$ is the equation of the contact curve of the part and the tool, which determines the position of the angular coordinate of the contact point on the tool depending on the current linear coordinate.

Knowing the position of the contact line, the original surface of the part can be formed by rotating it around the axis of the part. Finally, equation (10) of the surface of the machined part is written as

$$
\begin{gathered}
\bar{r}_{p}\left(\theta_{p}, i\right)=M^{3}\left(\theta_{p} \cdot t\right) \frac{S_{p}}{2 \cdot \pi} \cdot M^{6}\left(\theta_{p}\right) \times \\
\times M^{5}\left(\alpha_{m}\right) \cdot M^{3}(C) \cdot M^{2}\left(y_{c}\right) \times \\
\times M^{3}\left(Z_{m}(i)\right) \cdot M^{6}(L c(i)) \cdot M^{2}\left(R_{m}\left(z_{i}\right)\right) \cdot \bar{e} 4 .
\end{gathered}
$$

Graphical representation of equations $(15,16)$ and $(4)$ is shown in Fig. 4, which shows the treated surface of the part 1, the tool surface 2 and the line of their contact 3 .

As a result of rotation of a mill and its movement on a screw trajectory concerning position of a detail, in axial section there is a geometrical roughness. The predicted axial section of the part can be determined from the mathematical model (16), using a calculation unit similar to (14).

$$
S i_{1}=\mid \begin{aligned}
& k_{\min } \leftarrow 0 \\
& \text { for } j \in 0 . . N \\
& k \leftarrow k_{\min }+\frac{k_{\max }}{N} \cdot j \\
& x \leftarrow \bar{r}_{p}(k, 0)_{1,1} \\
& y \leftarrow \bar{r}_{p}(k, 0)_{2,1} \\
& M^{\langle j+1\rangle} \leftarrow\left(\begin{array}{l}
x \\
y
\end{array}\right) \\
& M^{T}
\end{aligned}
$$

where $k_{\min }=0, k_{\max }=B$ are minimum and maximum coordinates of points on the profile of the part in axial section, $\mathrm{mm}$; $N$ is the number of points on the part that are considered to determine the trace; $M$ is the coordinate matrix of trace points.

The results of modeling the profile of the part in the axial section are shown in Fig. 5 where line 1 is the nominal profile of the part; 2, 3 are contact lines of the cutter and the cylindrical surface. The distance from the nominal profile of the part

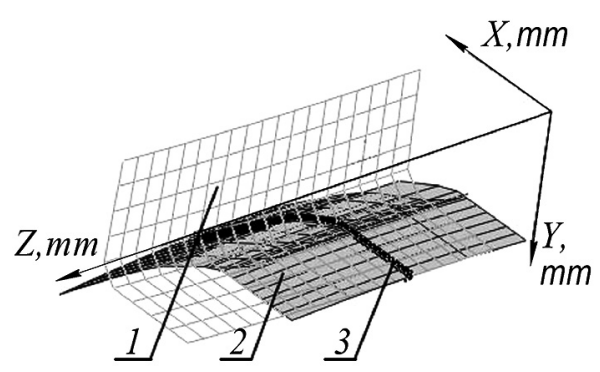

Fig. 4. Mathematical model of the process of milling a cylindrical surface

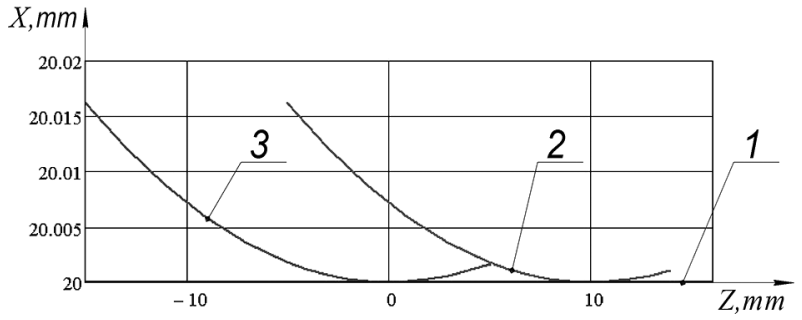

Fig. 5. Profile of a cylindrical surface when milling with an oriented tool

to the points of intersection of the trace lines determines the geometric roughness in the axial section.

The geometric surface roughness in the axial section is determined from the equation

$$
R\left(z_{1}\right)=S i_{1}\left(z_{1}\right)-r_{p}\left(z_{1}\right),
$$

where $z_{1}$ is a coordinate along the axis $O_{p} Z_{p}$ of the intersection of two consecutive traces of the cutter in the axial section, $\mathrm{mm}$.

The dependence of the change in geometric roughness on the angle of orientation of the tool during milling of the camshaft support necks is shown in Fig. 6. Analysis of the graph shows that the roughness in the axial section increases with increasing angle of rotation of the milling cutter.

In addition to the geometric roughness in the axial section, it is also necessary to consider the roughness in the radial section - waviness - when milling. It differs from a grinding wheel, when the tool surface is a solid disc surface. When milling, the tool surface in the form of a disk is formed by rotating a certain number of cutting blades arranged in a circle. In the case of constructing a mathematical spatial model of the process of removal of allowance and shaping, this feature is not significant. However, when studying the quality of the treated surface, in particular its roughness, it is necessary to take into account the discontinuity of the cutting tool surface.

Waviness is formed in radial section as a result of alternate contact with the workpiece surface milling cutting edges, which are located with a certain angular step. The scheme of formation of geometric roughness in radial section is given in Fig. 7. Due to the rotation of the milling cutter 1 , each of its teeth will cut the allowance area ECD; however, as a result of rotation of the part 2 and, accordingly, additional supply of material to the cutting zone, each tooth cuts the allowance cross section.

During the entry of the next tooth of the milling cutter into contact, its rotation at an angle $\theta_{m}$, the shaft rotates at an angle $\theta_{p}$, thereby, leaving the uncultivated area in the area of point $C$.

Fig. 7 shows that the current radius of the part when it comes into contact with the milling cutter tooth can be determined as

$$
r^{t}\left(\theta_{m}\right)=\sqrt{R_{m}^{2}+\left(R_{m}+r_{p}\right)^{2}-2 \cdot \cos \left(\theta_{m}\right) \cdot R_{m} \cdot\left(R_{m}+r_{p}\right)},
$$

where $r^{t}\left(\theta_{m}\right)$ is the current radius on the part in contact with the milling cutter tooth, $\mathrm{mm} ; \theta_{m}$ is the current angle of rotation of the milling cutter, rad.

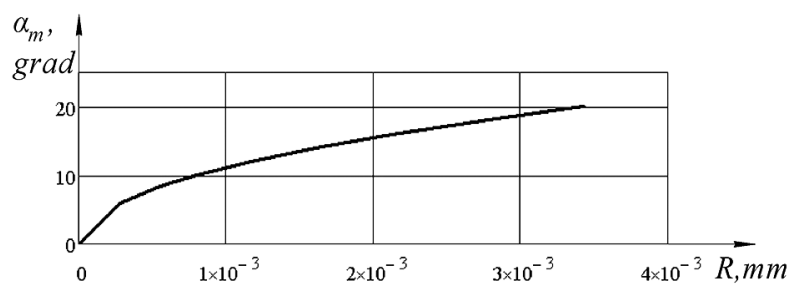

Fig. 6. Graph of the dependence of the geometric roughness in the axial section on the orientation angle of the milling cutter 


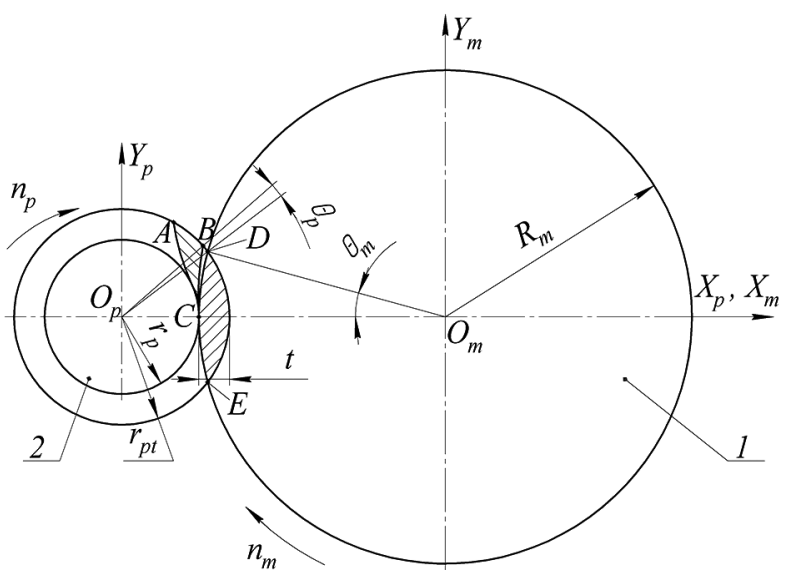

Fig. 7. Scheme for determining the roughness in the radial section

The corresponding angle of additional rotation of the detail is

$$
\theta_{p}^{t}\left(\theta_{m}\right)=a \cos \left(\frac{r^{t}\left(\theta_{m}\right)^{2}+\left(R_{m}+r_{p}\right)^{2}-R_{m}^{2}}{2 \cdot r^{t}\left(\theta_{m}\right) \cdot\left(R_{m}+r_{p}\right)}\right) .
$$

When studying the contact curve of each subsequent tooth of the milling cutter with the surface of the part angle, the current angle of rotation changes by some constant value

$$
\theta_{p}^{t i}\left(\theta_{m}\right)=\theta_{p}^{t}\left(\theta_{m}\right)+i \cdot \frac{2 \cdot \pi}{z \cdot k_{\omega}}
$$

where $\theta_{p}^{t i}\left(\theta_{m}\right)$ is the current angle of the detail rotation in contact with each $i^{\text {th }}$ tooth of the milling cutter, rad; $i=2 \ldots Z$ is a serial number of the milling cutter tooth, starting from the $2^{\text {nd }}$; $Z$ is the total number of the tool teeth; $k_{\omega}=\frac{\omega_{m}}{\omega_{p}}$ is a speed factor, which depends on the angular speed of rotation the milling cutter $\omega_{m}$ and tool $\omega_{p}$.

Accordingly, the current coordinates of the contact point of the milling cutter tooth and the shaft in the coordinate system of the detail are

$$
x_{p}^{t}\left(\theta_{m}\right)=r^{t}\left(\theta_{m}\right) \cdot \cos \left(\theta_{p}^{t}\left(\theta_{m}\right)\right) ; \quad y_{p}^{t}\left(\theta_{m}\right)=r^{t}\left(\theta_{m}\right) \cdot \sin \left(\theta_{p}^{t}\left(\theta_{m}\right)\right) .
$$

Interpolating a set of points, using equation similar to (15), we obtain the curves of the traces of each tooth of the milling cutter with the treated surface. Fig. 8 shows traces of two adjacent teeth of the milling cutter on the surface of the detail. The calculation was performed for machining a shaft with a diameter of $40 \mathrm{~mm}$, a milling cutter with a number of teeth $Z=12$. $\omega_{p}=30 \mathrm{~s}^{-1}$.

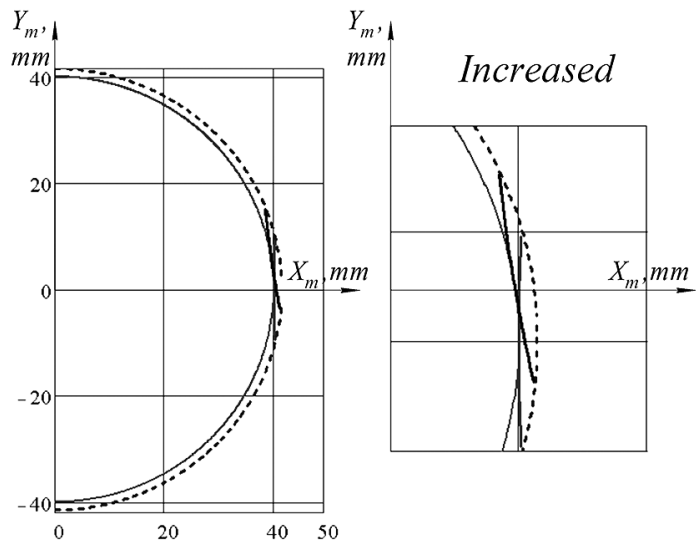

Fig. 8. Traces of the milling cutter teeth on the surface of the shaft
Angular speeds of rotation are $\omega_{p}=30 \mathrm{~s}^{-1}, \omega_{m}=110 \mathrm{~s}^{-1}$.

Waviness of cylindrical shaft flooding is defined as the distance from the point of intersection of two consecutive tracks to nominal range details

$$
R^{r}=r\left(\theta_{c r}\right)-r_{p}
$$

where $R^{r}$ is roughness in radial section, waviness, $\mathrm{mm} ; \theta_{c r}$ is the angle of intersection of two consecutive tracks, rad.

The dependence of the amount of ripple on the number of the milling cutter teeth is shown in Fig. 9. It is seen that with the increasing number of teeth of the tool the magnitude of the waviness decreases.

Determination of cutting forces is carried out by two main methods: theoretical and experimental, as well as their combination. To determine the cutting forces during grinding, the calculation and experimental method has become widespread. When calculating the unit cutting force acting on one grain, the number of grains involved in processing is considered and afterwards the total cutting force is determined. In the case of grinding, the number of working cutting edges is determined using the probability theory. When milling in the processing a certain number of cutting edges are involved, the number of which is easily determined by knowing the parameters of the tool and the machining scheme.

In milling, the total components of the cutting forces acting on one cutting blade can be defined as the sum of the forces on the front and rear surfaces [10]

$$
\begin{aligned}
& P_{n}=P_{1}+P_{1}^{\prime} ; \\
& P_{\tau}=P_{2}+P_{2}^{\prime},
\end{aligned}
$$

where $P_{n}$ is the normal component of cutting force; $P_{\tau}$ is the tangential component of the cutting force; $P_{1}, P_{2}$ are forces on the front surface; $P_{1}^{\prime}, P_{2}^{\prime}$ are forces on the back surface.

The components of the cutting forces can be determined as

$$
\begin{aligned}
& R_{n}=C_{t} \cdot a \cdot b+C_{f} \cdot \sum l_{\tau} ; \\
& R_{\tau}=U_{t} \cdot a \cdot b+U_{f} \cdot \sum l_{n},
\end{aligned}
$$

where $C_{t}, U_{t}$ are specific forces on the front surface; $C_{f}, U_{f}$ are specific forces on the rear surface; $a \cdot b$ is a cut area; $a, b$ are thickness and width of the cut; $\sum l_{n}, \sum l_{\tau}$ are projections of the total length of the working parts of the cutting edges on a plane perpendicular to the direction of the force.

The refined value of the cut area can be determined from the modular mathematical spatial model (16), as the area of the figure is limited by two consecutive traces of the tool surface in the axial plane and the workpiece surface (Fig. 5).

$$
a \cdot b=\int_{z_{3}}^{z_{1}} S_{p}(z) d z+\int_{z_{2}}^{z_{1}} S i_{1}(z) d z-\int_{z_{3}}^{z_{2}} S i_{2}(z) d z,
$$

where $S_{p}(z)=R_{p}+t$ is workpiece profile equation; $S i_{1}(z), S i_{2}(z)$ are equations of traces of two consecutive positions of the milling cutter $(1,2)$ in the axial plane of the camshaft; $z_{1}, z_{2}, z_{3}$

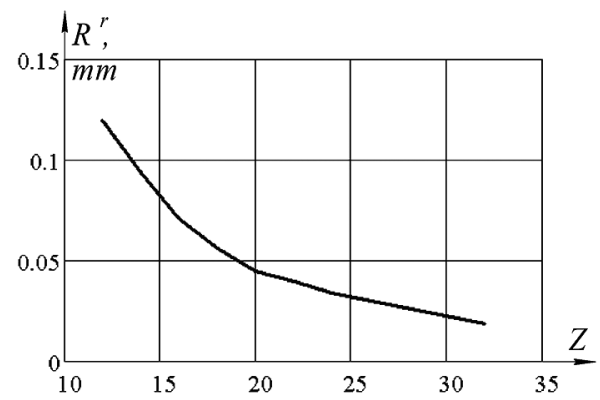

Fig. 9. Graph of the dependence of the roughness in radial section on the number of the milling cutter teeth 
are coordinates of points of intersection of the specified curves, mm.

Specific forces are calculated by equations [10]

$$
\begin{gathered}
C_{t}=\tau \cdot(\varepsilon+1) ; \\
U_{t}=\tau \cdot(\varepsilon+1) \cdot \operatorname{tg} \omega ; \\
C_{f}=1.5 \cdot \tau \cdot \varepsilon \cdot \rho+\mu \cdot \sigma_{t} \cdot h_{f} ; \\
U_{f}=1.5 \cdot \tau \cdot(3.17 \cdot \varepsilon+1) \cdot \rho \cdot \operatorname{tg} \omega+\sigma_{t} \cdot h_{f},
\end{gathered}
$$

where $\tau$ is tangential stress along the conditional shear plane; $\varepsilon$ is conditional shift; $\omega$ is an angle of action; $\rho$ is the radius of curvature of the cutting edge; $\mu$ is the coefficient of friction on the rear surface; $\sigma_{t}$ is border fluidity of material details; $h_{f}$ is the width of the wear site on the rear surface.

Conclusions. The general modular mathematical spatial model of the process of removing an allowance and formation at milling by the oriented tool of round surfaces of rotation, such as necks of camshafts, cylindrical surfaces of shafts of transmissions and others is constructed.

The roughness parameters of the treated surface are determined. The outflow of the tool characteristics and the angle of its orientation on the geometric roughness in the axial and radial sections is investigated. The area of the layer cut off by one tooth of a mill is defined. The calculation formulas for finding the components of cutting forces during milling are specified.

The found parameters allow predicting the initial machining accuracy by determining the parameters of geometric roughness in axial and radial sections, as well as the normal and tangential components of the cutting forces. That gives the chance to choose an optimum angle of orientation of the tool, parameters of a mill and cutting modes for achievement of high productivity and quality of processing.

\section{References.}

1. Kilic, Z. M., \& Altintas, Y. (2016). Generalized mechanics and dynamics of metal cutting operations for unified simulations. International Journal of Machine Tools and Manufacture, (104), 1-13. https://doi.org/10.1016/j.ijmachtools.2016.01.006. 2. Altintas, Y. (2016). Virtual High Performance Machining. Procedia CIRP, (46), 372-378. https://doi.org/10.1016/j. procir.2016.04.154.

3. Brechera, C., Wellmanna, F., \& Epplea, A. (2017). Qualitypredictive CAM simulation for NC milling. Procedia Manufacturing, (11), 1519-1527. https://doi.org/10.1016/j.promfg. 2017.07.284.

4. Altintas, Y., \& Tulsyan, S. (2015). Prediction of part machining cycle times via virtual CNC. CIRP Annals - Manufacturing Technology, (64/1), 361-364. https://doi.org/10.1016/j. cirp.2015.04.100.

5. Rubeo, M.A., \& Schmitz, T. L. (2016). Global stability predictions for flexible workpiece milling using time domain simulation. Journal of Manufacturing Systems, (40/2), 8-14. https://doi.org/10.1016/j.jmsy.2016.05.003.

6. Zavarzin, D.A., Kiselev, I.A., \& Tsyganov, D.L. (2016). Flat Milling Process Simulation Taking into Consideration a Dependence of Dynamic Characteristics of the Machine. $\mathrm{Ma}$ chines and Plants: Design and Exploiting, (4), 53-68. https:// doi.org/10.7463/aplts.0416.0845919.

7. Vnukov, Yu. N., Dyadya, S. I., \& Kozlova, E. B. (2016). On the influence of the design and geometrical characteristics of end mills on the vibration resistance of the milling process. Cutting \& tools in technological systems, (86), 7-17.

8. Kalchenko, V., Kalchenko, V., Kalchenko, O., Sira, N., Kalchenko, D., Morochko, V., \& Vynnyk, V. (2020). Development of a model of tool surface dressing when grinding with crossed wheel and cylindrical part axes. Eastern-European Journal of Enterprise Technologies, (3), 23-29. https://doi. org/10.15587/1729-4061.2020.202441.

9. Kalchenko, V., Kalchenko, V., Sira, N., Kalchenko, O., Vynnyk, V., Kalchenko, D., \& Morochko, V. (2020). Develop- ment of the single-setup milling process model of the shaft support necks and cams. Eastern-European Journal of Enterprise Technologies, (4), 48-54. https://doi.org/10.15587/17294061.2020.208579.

10. Vnukov, Yu.N., Dyadya, S.I., \& Kozlova, E.B. (2016). Evolution of development of research on forces in cylindrical milling from static to dynamic processing conditions. Modern technologies of engineering, (11), 20-41.

\section{Визначення складових сил різання при фрезеруванні циліндричних поверхонь орієнтованим інструментом}

\section{В. В. Кальченко ${ }^{1}$, С. Д. Цибуля 1 , А. В. Кологойда ${ }^{1}$,} Е. Ю. Сахно ${ }^{2}$, С. В. Бойко

1 - Національний університет «Чернігівська політехніка», м. Чернігів, Україна, e-mail: svboyko.cstu@gmail. com 2 - Чернігівський державний інститут економіки та управління, м. Чернігів, Україна

Мета. Побудова загальної модульної математичної просторової моделі процесу зняття припуску та формоутворення при фрезеруванні круглих поверхонь обертання, таких як шийки розподільних валів, циліндричні поверхні валів коробок передач і інших. Визначення складових сил різання при обробці зі схрещеними осями фрези й деталі задля використання отриманих результатів при призначенні режимів обробки.

Методика. Теоретична розробка модульної математичної моделі процесу зняття припуску та формоутворення при фрезеруванні циліндричних поверхонь проводилась із використанням матричного апарату перетворення систем координат. Були використані розроблені уніфіковані модулі: інструментальний, орієнтації та формоутворення, що дозволило більш наочно описати процес обробки деталі. Здійснення всіх розрахунків проводилося в математичному пакеті Mathcad. Із використанням доступних у пакеті функцій отримано графічне відображення математичної моделі інструментальної та обробленої поверхні. За допомогою розроблених у програмі логічних блоків досліджені характеристики обробленої поверхні, такі як шорсткість в осьовій і радіальній площинах. Досліджено вплив кута орієнтації інструмента й кількості зубів фрези на шорсткість обробленої поверхні. Уточнені відомі формули розрахунку сил різання при фрезеруванні.

Результати. Побудована загальна модульна математична просторова модель процесу зняття припуску та формування при фрезеруванні орієнтованим інструментом круглих поверхонь обертання, таких як шийки розподільних валів, циліндричні поверхні валів трансмісій та ін. Визначені параметри шорсткості обробленої поверхні. Було досліджено витікання характеристик інструменту й кут його орієнтації на геометричні шорсткості в осьовому й радіальному перетинах. Визначена площа шару, зрізаного одним зубом фрези. Вказані розрахункові формули для знаходження складових сил різання при фрезеруванні.

Наукова новизна. Запропонована модульна просторова модель процесу фрезерування циліндричних поверхонь орієнтованим інструментом, на базі якої розраховані складові сил різання, що може бути використано при конструюванні нових інструментів і поліпшенні умов обробки існуючими.

Практична значимість. Із використанням сучасного комп'ютерного обладнання та програмного забезпечення, створена розрахункова програма дозволяє керувати процесом формоутворення циліндричних поверхонь при ï фрезеруванні орієнтованим інструментом. Також до- 
зволяє прогнозувати вихідну точність обробки за рахунок визначення параметрів геометричної шорсткості в осьовому й радіальному перерізах, а також нормальної й тангенціальної складових сил різання. Це дає можливість обирати оптимальний кут орієнтації інструменту, параметри фрези й режими різання для досягнення високої продуктивності та якості обробки.

Ключові слова: сили різання, фрезерування, розподільний вал, шліфування, моделювання, шорсткість

\section{Определение составляющих силы резания при фрезеровании цилиндрических поверхностей ориентированным инструментом}

\section{В. В. Кальченко ${ }^{1}$ С. Д. Цибуля ${ }^{1}$, А. В. Кологойда ${ }^{1}$, Е. Ю. Сахно ${ }^{2}$ С. В. Бойко}

1 - Национальный университет «Черниговская политехника», г. Чернигов, Украина, e-mail: svboyko.cstu@gmail.com 2 - Черниговский государственный институт экономики и управления, г. Чернигов, Украина

Цель. Построение общей модульной математической пространственной модели процесса снятия припуска и формообразования при фрезеровании круглых поверхностей вращения, таких как шейки распределительных валов, цилиндрические поверхности валов коробок передач и других. Определение составляющих сил резания при обработке со скрещенными осями фрезы и детали для использования полученных результатов при назначении режимов обработки.

Методика. Теоретическая разработка модульной математической модели процесса снятия припуска и формообразования при фрезеровании цилиндрических поверхностей проводилась с использованием матричного аппарата преобразования систем координат. Были использованы разработанные унифицированные модули: инструментальный, ориентации и формообразования, что позволило более наглядно описать процесс обработки детали. Осуществление всех расчетов проводилось в математическом пакете Mathcad. С использованием доступных в пакете функций получено графическое отображение математической модели инструментальной и обработанной поверхности. При помощи разработанных в программе логических блоков исследованы характеристики обработанной поверхности, такие как шероховатость в осевой и радиальной плоскостях. Исследовано влияние угла ориентации инструмента и количества зубьев фрезы на шероховатость обработанной поверхности. Уточнены известные формулы расчета сил резания при фрезеровании.

Результаты. Построена общая модульная математическая пространственная модель процесса снятия припуска и формирования при фрезеровании ориентированным инструментом круглых поверхностей вращения, таких как шейки распределительных валов, цилиндрические поверхности валов трансмиссий и др. Определены параметры шероховатости обработанной поверхности. Было исследовано истечение характеристик инструмента и угол его ориентации на геометрические шероховатости в осевом и радиальном сечениях. Определена площадь слоя, срезанного одним зубом фрезы. Указаны расчетные формулы для нахождения составляющих сил резания при фрезеровании.

Научная новизна. Предложена модульная пространственная модель процесса фрезерования цилиндрических поверхностей ориентированным инструментом, на базе которой рассчитаны составляющие сил резания, что может быть использовано при конструировании новых инструментов и улучшении условий обработки существующих.

Практическая значимость. С использованием современного компьютерного оборудования и программного обеспечения, созданная расчетная программа позволяет управлять процессом формообразования цилиндрических поверхностей при их фрезеровании ориентированным инструментом. Также позволяет прогнозировать исходную точность обработки за счет определения параметров геометрической шероховатости в осевом и радиальном сечениях, а также нормальной и тангенциально составляющих сил резания. Это дает возможность выбирать оптимальный угол ориентации инструмента, параметры фрезы и режимы резания для достижения высокой производительности и качества обработки.

Ключевые слова: силы резания, фрезерование, распределительный вал, илифование, моделирование, шероховаmocms

Recommended for publication by H.P. Bolotov, Doctor of Technical Sciences. The manuscript was submitted 28.12.20. 